\title{
RESISTANT CYCLIC VOMITING SYNDROME SUCCESSFULLY RESPONDING TO CHLORPROMAZINE
}

\author{
Hasan H. Özdemir', Serpil Bulut ${ }^{2}$, M. Said Berilgen, Oktay Kapan ${ }^{3}$ Metin Balduz', Caner F. Demir ${ }^{2}$
}

Dicle University Neurology Department, Diyarbakır, Turkey ${ }^{1}$, Firat University Neurology, Elazığ, Turkey ${ }^{2}$, Yüksekova State Hospital Neurology, Hakkari, Turkey ${ }^{3}$

Summary: Cyclic vomiting syndrome (CVS) is a disorder characterized by recurrent, stereotypic episodes of nausea, vomiting, and other symptoms, separated by intervals of comparative wellness. These episodes carry on for hours or days. The patient is healthy between the episodes and has no clinical finding. For the treatment of the CVS, antiemetic, antimigraine and sedative medications were used. However, in some cases CVS treatment is very difficult. We report about a young patient, who did not respond to many agents, but was succesfully treated with chlorpomazine

Key words: Cyclic vomiting syndrome; Chlorpromazine

\section{Introduction}

Cyclic vomiting syndrome is a stereotypical disease, which is characterized by recurrent episodic attacks of severe nausea and vomiting (1). Recurrent vomiting may be associated with abdominal migraine, abdominal epilepsy, migraine equivalents, duplication cysts and abdominal pain with gastrointestinal abnormalities which are recurrent like malrotation. Even if many organic diseases appear with cyclic and recurrent vomiting pattern, CVS has been observed primarily as a dysfunction of the central nervous system caused by migraine (2). The treatment is important because CVS may negatively affect patients' quality of life.

\section{Case}

A 19-year-old female patient presented to our clinic with symptoms of nausea and vomiting, which occured 10 to 12 times per year since 7 years, lasting 6-7 days. In her medical history she didn't showed concomitant headache attacks. CVS was diagnosed by excluding other causes of recurrent vomiting. Her mother has been followed up with a diagnosis of migraine. The patient didn't benefit from prophylactic therapy of amitriptyline $(35 \mathrm{mg} /$ day $)$, topiramate $(50 \mathrm{mg} /$ day $)$, flunarizine $(10 \mathrm{mg} /$ day $)$, propranolol (100 mg/day), erythromycin (1 gr/day), cyproheptadine $(10 \mathrm{mg} /$ day $)$ and from the acute therapy of ondansetrone ( $4 \mathrm{mg} /$ day), dimenhydrinate $(100 \mathrm{mg} /$ day), metoclopramide $(15 \mathrm{mg} /$ day $)$ in the vomiting phase. The patient's blood pressure, laboratory tests, electroencephalography (ECG) and cranial MRI were normal. Her initial evaluation by a gastroenterologist including laboratory studies (complete blood count, metabolic panel including liver function tests, amyl- ase, lipase, and a urinalysis), abdominal ultrasonography, abdominal pelvic computed tomography, routine barium studies and endoscopic evaluation were normal. Although no significant pathology was observed, she received treatment for acid peptic disease but she was unresponsive. The patient was hydrated and $0.2 \mathrm{mg} / \mathrm{kg}$ chlorpromazine intravenous was administered 2 times a day in $1000 \mathrm{cc}$ of saline. On the first day of treatment the patient's symptoms began to diminish. After three days of treatment the patient recovered completely. Ultimately, a trial of chlorpromazine orally $0.25 \mathrm{mg} / \mathrm{kg} /$ day, was given during the vomiting phase. She took chlorpromazine along 3-4 days per month. After six months following, vomiting intervals and periods decreased. Also, symptoms were completely resolved at the end of the first year. In order to evaluate the side effects of chlorpromazine; regular blood tests, ECG and eye examinations were performed. Drug-related side effects were not observed.

\section{Discussion}

In literature it has been suggested that CVS is a manifestation of migraine (1). In general, it starts suddenly, repeats at regular intervals and it can take hours or days. Vomiting attacks show the stereotype of the typical feature of the disease. During attacks, symptoms may accompany to vomiting like nausea, abdominal pain, photophobia, fever, pallor, dehydration and social isolation. Between the attacks, the patient is completely healthy (2). Other authors report that it have been accused of hormonal dysfunction, mitochondrial gene mutations, gastrointestinal dysrhythmias, food allergy, autonomic dysfunction and ion channelopathies $(3,4)$. In etiology, infection, psychological stress and menstruation can initiate vomiting attacks (5). The typical symptoms of 
Tab. 1: Treatment of prophylactic and vomiting phase of CVS.

\begin{tabular}{|l|l|}
\hline Prophylaxis & Vomiting phase \\
\hline $\begin{array}{l}\text { Amitriptyline } \\
(0.25-1.5 \mathrm{mg} / \mathrm{kg} / \mathrm{day})\end{array}$ & $10 \%$ glucose IV \\
\hline $\begin{array}{l}\text { Propranalol } \\
(0.25-1 \mathrm{mg} / \mathrm{kg} / \mathrm{day})\end{array}$ & $\begin{array}{l}\text { Ondansetron } \\
(0.3-0.4 \mathrm{mg} / \mathrm{kg}) \mathrm{IV}\end{array}$ \\
\hline Erythromycin $(20 \mathrm{mg} / \mathrm{kg} /$ day $)$ & Omeprazole $(1 \mathrm{mg} / \mathrm{kg} /$ day $) \mathrm{IV}$ \\
\hline $\begin{array}{l}\text { Coenzyme Q10 } \\
(10 \mathrm{mg} / \mathrm{kg} / \mathrm{day})\end{array}$ & $\begin{array}{l}\text { Lorazepam } \\
(0.05-0.1 \mathrm{mg} / \mathrm{kg} / \mathrm{day}) \mathrm{IV}\end{array}$ \\
\hline $\begin{array}{l}\text { Carbamazepine } \\
(5-10 \mathrm{mg} / \mathrm{kg} / \mathrm{day})\end{array}$ & $\begin{array}{l}\text { Chlorpromazine } \\
(0.15-0.3 \mathrm{mg} / \mathrm{kg} / \mathrm{day}) \mathrm{IV}\end{array}$ \\
\hline $\begin{array}{l}\text { Cyproheptadine } \\
(0.25-0.5 \mathrm{mg} / \mathrm{kg} / \mathrm{day}) \\
(5 \text { year or younger) }\end{array}$ & $\begin{array}{l}\text { Diphenhydramine } \\
(1.0-1.25 \mathrm{mg} / \mathrm{kg} / \mathrm{day}) \mathrm{IV}\end{array}$ \\
\hline $\begin{array}{l}\text { Pizotifen }(0.5-1.0 \mathrm{mg} / \mathrm{day}) \\
(5 \text { year or younger) }\end{array}$ & $\begin{array}{l}\text { Sumatriptan Oral } 25-50 \mathrm{mg}, \\
\text { intranasal } 10 \mathrm{mg}, \\
\text { or subcutaneously } 3-6 \mathrm{mg} \\
(\text { Older than } 18 \text { year })\end{array}$ \\
\hline
\end{tabular}

the patients point to CVS diagnosis, but for making the diagnosis it is important to exclude other causes of recurrent vomiting by laboratory, radiographic, and endoscopic testing (6).

Treatment of CVS is still not evidence based (1). Specific management recommendations are based on the individual phase of the cyclic vomiting cycle (7). Prophylaxis of symptomatic vomiting episodes focusses on the identification and avoidance of triggering factors as well as prophylactic drugs. If a concomitant migraine exists, CVS prophylactic treatment should include prophylaxis of migraine during the inter-episodic phase. A daily dose of amitriptyline, propranalol or cyproheptadine may decrease the frequency or duration of episodes $(9,10)$. Also, drugs such as pizotifen, carbamazepine, erythromycin, coenzyme Q10 can be used for CVS prophylaxis (Table 1) (8-10).

As for that therapeutic purposes in vomiting phase is the prevention of dehydration, renal failure, tetany, hematemesis and inappropriate antidiuretic hormone release (1).
For this purpose 5\% dextrose, ondansetrone, lorazepam, omeprazole can be used in vomiting phase (Table 1). Additionaly, triggers of vomiting episodes or anxiety as chronic infection, menstrual syndrome cases should be identified and treated (9).

Chlorpromazine is a conventional antipsychotic drug. The basic mechanism of chlorpromazine is the high affinity and antagonism towards dopaminergic D2 receptors. Its antiemetic feature is known, but only a few publications report about its effectiveness in CVS (9). In chlorpromazine treatment, it is important to follow side effects resulting from the treatment.

In our patient, there were episodes of nausea and vomiting that did not respond to many treatment regimens. The patient's symptoms decreased with intravenous chlorpromazine in vomiting phase. Thus, we chose oral chlorpromazine for the treatment. We observed, that chlorpromazine, which was used in periods of vomiting, improved the patient fully. Side effects were not observed during follow-up. We want to emphasize with presentation of this case, that chlorpromazine could be effective in patients with resistant CVS.

\section{References}

1. Headache Classification Subcommittee of the International Headache Society The International Classification of Headache Disorders: 2nd edition. Cephalalgia. 2004; 24 : 9-160.

2. Weinstein M. Underlying disorders in cyclic vomiting syndrome. Clin Pediat (Phila) 2005; 44: 805-807.

3. Li BUK, Murray RD. Is cyclic vomiting related to migraine? J Pediatr 1999; 134: 567-72

4. Mitchell WG, Greenwood RS, Messenheimer JA. Abdominal epilepsy: Cyclic vomiting as the major symptom of simple partial seizures. Arch Neurol 1983; 40: 251-252.

5. Scarcia S, Fiumana E, Gnoato R, et al. Etiology and precipitating factors of cyclic vomiting. Pediatr Med Chir 2000; 22: 25-29.

6. Li BU, Lefevre F, Chelimsky GG, et al. North American Society for Pediatric Gastroenterology, Hepatology, and Nutrition consensus statement on the diagnosis and management of cyclic vomiting syndrome. J Pediatr Gastroenterol Nutr. 2008; 47(3): 379

7. Kowalczyk M, Parkman H, Ward L. Adult cyclic vomiting syndrome successfully treated with intranasal sumatriptan. J Gen Intern Med. 2010 Jan; 25(1): 88-91.

8. Boles RG, Lovett-Barr MR, Preston A, Li BU, Adams K. Treatment of cyclic vomiting syndrome with co-enzyme Q10 and amitriptyline, a retrospective study. BMC Neurol. 2010; 10: 10

9. Forbes D, Fairbrother S. Cyclic nausea and vomiting in childhood Aust Fam Physician. 2008 Jan-Feb; 37(1-2): 33-6

10. Yang HR. Recent concepts on cyclic vomiting syndrome in children. J Neurogastroenterol Motil. $2010 \mathrm{Apr}$; 16(2): 139-47.

\section{Corresponding author:}

Hasan Hüseyin Özdemir, M.D., Dicle University Neurology Department, Diyarbakır, Turkey; e-mail: drhasanh@gmail.com 